\title{
Recenzje
}

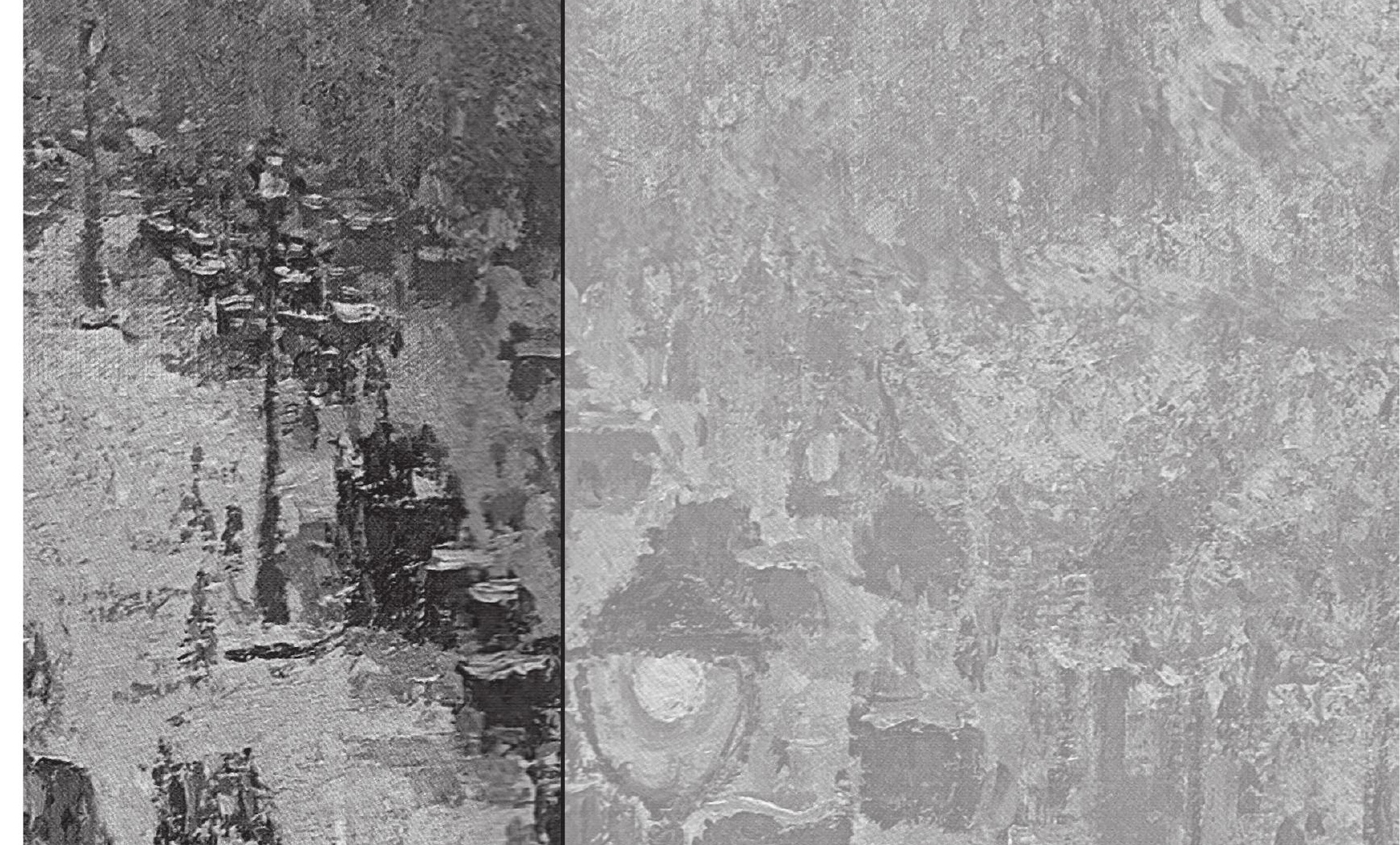



L. Martinek, M. Gamrat, Literatura i muzyka. Wprowadzenie do problematyki, Literature\&Sciences, Opava 2017

\section{Raz jeszcze o literaturze i muzyce}

ABSTRACT. Walczak Jakub, Raz jeszcze o literaturze i muzyce [Once again about literature and music]. „Przestrzenie Teorii” 29. Poznań 2018, Adam Mickiewicz University Press, pp. 359-364. ISSN 1644-6763. DOI 10.14746/pt.2018.29.16.

The article deals with the still relevant interdisciplinary research movement, which chose the relation between music and literature as the object of its analysis. The book by Libor Martinek and Małgorzata Gamrat, which is the result of cooperation between a literary scholar and a musicologist, is the main basis for and contribution to this discussion. Following the path set by P. Scher, these authors have found a methodological dimension, on which issues of literary text functioning in the music sphere are located, and on the other hand, attempts to define a so-called literary text's musical aspects.

KEYWORDS: Literature and music, intermediality, interdisciplinarity, musicality of literature

Książka Libora Martinka i Małgorzaty Gamrat Literatura i muzyka. Wprowadzenie do problematyki wpisuje się w aktualny nurt badań interdyscyplinarnych, które za przedmiot swoich analiz obrały wzajemne relacje muzyki i literatury. Literaturoznawcy i muzykolodzy znaleźli metodologiczną płaszczyznę, na której z jednej strony znajdują się zagadnienia funkcjonowania tekstu literackiego w przestrzeni muzyki, z drugiej zaś próby definiowania tak zwanej muzyczności dzieła literackiego. Płaszczyzna ta, precyzyjnie określona przez Stevena P. Schera ${ }^{1}$, stwarza możliwość szerokich studiów muzyczno-literackich, czy tė̇ literacko-muzycznych, które różni zasadniczo przedmiot badań. Moga być nim gatunki muzyczne, w których strukturze znajduje się słowo: analizuje się tu bezpośredni wpływ słowa na materię muzyczna, jaki obserwujemy w gatunkach wokalno-instrumentalnych (nurt: muzyka i literatura). Inne kierunki badawcze prowadza do wskazania i zdefiniowania roli literatury w instrumentalnej muzyce programowej (nurt: literatura w muzyce). Trzeci zaś nurt - muzyka $\mathrm{w}$ literaturze, to przyglądanie się takim zagadnieniom jak: kształtowanie

${ }^{1}$ Por. S.P. Scher, Literature and music, [w:] Word and Music Studies. Essays on Literature and Music (1967-2004) by Steven Paul Scher, ed. W. Bernhart, W. Wolf, AmsterdamNew York 2004, s. 192. 
brzmieniowe tekstu, wykorzystanie technik quasi-kompozytorskich w formowaniu struktury utworów literackich, czy też szeroko rozumianym muzycznym inklinacjom w literaturze pięknej.

W myśl tego interdyscyplinarnego podziału autorzy książki Literatura i muzyka. Wprowadzenie do problematyki, podejmując próbę przedstawienia w bardzo zwartej formie najważniejszych zagadnień, wyodrębnili w swojej pracy trzy zasadnicze obszary, jakie odnajdujemy w studiach muzyczno-literackich. Obszary te stały się podstawą selekcji treści i prezentowania materiału w opracowaniu L. Martinka i M. Gamrat. Jest to już drugie, poszerzone wydanie książki, nieco zmienione względem pierwszego z roku 2015. Znalazły się w nim informacje i zagadnienia, których zabrakło w pierwszej edycji; na uwagę zasługuje też fakt, że doprecyzowano aparat pojęciowy z zakresu relacji literatury i muzyki.

W pierwszej części (Literatura i muzyka. Elementy wspólne) prezentuje się zwięzły przegląd koncepcji dotyczących twórczości literackiej i muzycznej, podkreślając fakt wspólnoty obu dziedzin sztuki od ich zarania, w tym także wspólnoty na poziomie stosowanych terminów i pojęć oraz nazw gatunków. Czytelnik otrzymuje zwięzłą informację dotycząca głównych zagadnień poruszanych w badaniach nad muzyką i literaturąjako systemami dźwiękowymi i retorycznymi - autorzy w interesujący sposób prezentują interakcje obu sztuk na wzajemnie przenikających się płaszczyznach (między innymi utwór literacki i muzyczny jako komunikat; wzajemny wpływ muzyki i literatury na poziomie kompozycji - motyw muzyczny, motyw literacki; muzyka i literatura jako systemy ,językowe” itd., s. 13-17). Skoro zaś poruszono problem strukturalnych podobieństw obu systemów i ich strategii komunikacyjnych, dodatkowo można by odnieść się do koncepcji semiotyki muzyki takich teoretyków i badaczy jak E. Tarasti, J.J. Nattiez, czy G. Stefani.

Druga cześć książki, zatytułowana Muzyka i literatura. Rozwój zagadnienia w perspektywie historycznej, największa pod względem objętościowym, stanowi zasadniczy trzon publikacji. Autorzy starali się w możliwie zwięzłej formie zaprezentować historię muzyki, skupiając się przede wszystkim, choć nie jedynie, na gatunkach muzyki wokalnej, w której obecny jest pierwiastek literacki. Materiał pogrupowany jest w sposób przejrzysty i konsekwentny, odpowiadający przyjętym podziałom na epoki (starożytność, średniowiecze, renesans, barok itd., po okres powojenny XX wieku); każdej z nich poświęcono proporcjonalnie tyle samo uwagi. W poszczególnych działach odnajdziemy krótką charakterystykę najbardziej typowych dla danej epoki gatunków; przywołuje się także nazwiska bardziej znaczących kompozytorów oraz ich utwory, które zapisały się na stałe w historii muzyki. Cennym wkładem jest przywoływanie historii rozwoju muzyki w krajach słowiańskich na tle ogólnoeuropejskim. 
To dobrze, że, względem wydania pierwszego, w omawianym wydaniu drugim w części poświęconej muzyce barokowej znalazła się informacja na temat złożonego systemu retorycznego w muzyce wokalno-instrumentalnej tego okresu, który właściwie jest kwintesencja, jeśli chodzi o związki słowno-muzyczne (s. 37-38). Już w XVI wieku dla włoskich teoretyków muzyki oraz twórców polifonii centralnym zagadnieniem było współistnienie literatury i muzyki, a ich dociekania dotyczyły wiedzy o poezji, retoryce i gramatyce; sięgając także do antyku, próbowali wydobyć genezę tych kategorii, dzięki którym opisać można relacje muzyki ze słowem ${ }^{2}$. Niejako kontynuacją i rozwinięciem tej działalności była refleksja teoretyczna oraz twórczość kompozytorów epoki baroku, którzy usystematyzowali figury poetycko-muzyczne, składające się na imponująca wiedzę o uczuciach (niem. Affektenlehre), przypisując określonej figurze muzycznej z góry określony afekt w celu wzmocnienia relacji pomiędzy muzyką a tekstem literackim, na którym opierała się kompozycja ${ }^{3}$.

Z kolei w częściach dotyczących rozwoju opery można by jeszcze bardziej wyeksponować kwestię doboru tekstów literackich, będących podstawą librett. Trzeba powiedzieć, że historia muzyki scenicznej to także po części historia libretta i dyskusji kompozytorów, librecistów oraz teoretyków na temat jego (libretta) znaczenia dla dramaturgii spektaklu muzycznego. Odbywający się od zarania opery spór dotyczył zawsze rozstrzygnięcia zasadniczej kwestii: pierwszeństwa pierwiastka literackiego nad muzycznym (prima le parole, poi la musica) i na odwrót (prima la musica, poi le parole) $)^{4}$. Każda operowa epoka, począwszy od działalności Cameraty florenckiej, na nowo próbowała definiować znaczenie użytego tekstu, jego wartość poetycką i dramaturgiczna wewnątrz dzieła muzycznego; kompozytorzy i współpracujący z nimi ściśle libreciści zdawali sobie mocno sprawę, choć w każdej epoce interpretowali to na swój sposób, z konsekwencji współistnienia warstwy tekstowej i treściowej z pozostałymi elementami składającymi się na całość opery, która od swych początków miała być przecież idealnym urzeczywistnieniem ducha greckiego dramatu; zawsze zaś celem nadrzędnym było dążenie do ich spójności ${ }^{5}$.

${ }^{2}$ Zob. np. R.J. Wieczorek, Ut cantus consonet verbis. Zwiazki muzyki ze słowem we wtoskiej refleksji muzycznej XVI wieku, Poznań 1995.

${ }^{3}$ Zob. między innymi D. Harrán, Word-Tone Relations in Musical Thought. From Antiquity to the Seventeenth Century, Neuhausen-Stuttgart 1986; N. Harnoncourt, Muzyka mowa dźwięków, przeł. M. Czajka, Warszawa 1995; T. Jasiński, Polska barokowa retoryka muzyczna, Lublin 2006.

${ }^{4}$ J. Walczak, Libretto jako (u)twór. Zagadnienia genologiczne i metodologiczne - zarys problematyki, „Przestrzenie Teorii” 2014, nr 22, s. 95.

${ }^{5} \mathrm{Na}$ ten temat zob. więcej: P.J. Smith, The Tenth Muse: A Historical Study of the Opera Libretto, New York 1970; K.D. Link, Literarische Perspektiven des Opernlibrettos: Studien zur italienischen Oper von 1850 bis 1920, Bonn 1975; K. Kozłowski, O libretcie, przemianach 
Istotne kwestie dotyczące współzależności muzyki i poezji odnajdziemy w części zatytułowanej Romantyczna liryka wokalna (s. 53-54). To w pieśni romantycznej, która stała się właściwie symbolem epoki, realizuje się w pełni idea związku literatury i muzyki; samo już określenie liryka wokalna niesie za sobą syntezę obu sztuk, a pojęcia stosowane w definiowaniu pieśni zarówno w poetyce, jak i w muzykologii sugerują niemal organiczną jedność słowa i dźwięku w tym gatunku. „W formie pieśni - jak słusznie stwierdza Bohdan Pociej - słowo doświadcza muzyki najbardziej bezpośrednio i naturalnie" ${ }^{6}$. Utrwalona w nauce o muzyce koncepcja związków słowno-muzycznych opiera się, mówiąc w największym skrócie, na zależności pomiędzy słowem obecnym w utworze muzycznym (dotyczy to literatury wokalnej) a pozostałymi jego elementami: przede wszystkim rytmem, melodia, harmonia. Chodzi tu o wyrazową i formalną zależność pomiędzy tekstem a muzyką. Z jednej strony o właściwościach utworu muzycznego decydują walory wyrazowe tekstu (najczęściej poetyckiego), z drugiej zaś kompozytor kieruje się także konstrukcją tekstu i uwydatnia ją za pomocą środków muzycznych ${ }^{7}$. Pewną kontynuacją tej tematyki, czy też dopowiedzeniem i uzupełnieniem są rozważania, jakie odnajdziemy w ostatnich podrozdziałach (Czeska muzyka popularna i Muzyka ludowa) drugiej części książki L. Martinka i M. Gamrat, gdzie czytamy, iż „podczas śpiewu, któremu towarzyszy muzyka, wykonawca uwzględnia wymogi śpiewanego tekstu, a struktura muzyczna łączy się z nim w taki sposób, że obie płaszczyzny wybrzmiewaja jednocześnie i funkcjonują jako specyficzny znak estetyczno-artystyczny"8.

Ostatnia, stosunkowa nieduża pod względem objętościowym, trzecia część książki zatytułowana jest Muzyka w literaturze. Zagadnienia wstep$n e$. Słusznie autorzy podkreślili, że czytelnik otrzyma jedynie wstępne informacje na temat takich kwestii jak: pozaliterackie, muzyczne inspiracje obecne w utworach poetyckich i w prozie, czy też odszukiwanie struktur

w jego rozumieniu i jedności dramatu muzycznego, „Poznańskie Studia Polonistyczne”, Seria Literacka V (XXV), Poznań 1998.

${ }^{6}$ B. Pociej, Mahler, Kraków 1992, s. 125.

${ }^{7} \mathrm{Na}$ ten temat zob. między innymi M. Bristiger, Zwiazki muzyki ze stowem. $Z$ zagadnień analizy muzycznej, Warszawa 1986; M. Tomaszewski, W stronę teorii pieśni: zwiazki słowno-muzyczne, [w:] tegoż, Nad pieśniami Karola Szymanowskiego. Cztery studia, Kraków 1998; B. Pociej, Istota pieśni, „Zeszyty Naukowe Akademii Muzycznej im. I.J. Paderewskiego w Poznaniu”, z. II, Poznań 1982; V. Kostka, Pieśn solowa przez pryzmat zwiqzków muzyki ze stowem, „Zeszyty Naukowe Akademii Muzycznej im. S. Moniuszki w Gdańsku”, z. XXIXXXX, Gdańsk 1991; M. Tomaszewski, Od wyznania do wołania. Studia nad pieśnia romantyczna, Kraków 1997.

${ }^{8}$ L. Martinek, M. Gamrat, Literatura i muzyka. Wprowadzenie do problematyki, Opava 2017, s. 90 . 
muzycznych w literaturze. Porusza się tu - mówiąc w największym skrócie - problem analizy i interpretacji obecności pierwiastka muzycznego w utworach literackich. Na wstępie znajdziemy zrekonstruowany stan badań oraz próbę odpowiedzi na pytanie, jak zrodziła się potrzeba podejmowania wysiłku odnajdowania muzycznych inspiracji w utworach literackich. Literaturoznawstwo, przede wszystkim dzięki osiagnięciom komparatystyki, dopuszcza rozszerzenie kręgu swych badań o refleksję na temat korelacji literatury z innymi dziedzinami sztuki, ciągle uwzględniając jednak mechanizmy literackie, czyli operacje dokonywane na słowie. Naczelnym zaś wyzwaniem dla takich studiów jest wspomniana analiza i interpretacja pozaliterackich inspiracji, które realizują się w postaci specyficznego ukształtowania językowego i dźwiękowego tekstu czy też w postaci rozmaitych struktur muzycznych, mających wpływ na kompozycję tekstu literackiego. Słusznie zaznacza L. Martinek, że muzyczność dzieła literackiego nie ogranicza się do dźwiękowego aspektu języka; z drugiej zaś strony „kompozycja 'muzyczna' nie może w utworze zastapić kompozycji literackiej, może ją jedynie stylistycznie przypominać - i to tylko częściowo"9.

Trzeba podkreślić niewątpliwy atut publikacji w postaci spisów bibliograficznych po każdym podrozdziale. Widać, że autorzy dobrze zorientowani są w literaturze przedmiotu, o czym świadczy także bibliografia umieszczona na końcu książi. Występują w niej nie tylko klasyczne opracowania z zakresu muzykologii i literaturoznawstwa oraz publikacje interdyscyplinarne, które z racji podjętej tematyki powinny były się tam znaleźć, ale odnajdziemy także rzadziej przywoływane pozycje warte uwagi, między innymi autorów czeskich.

Pomyślana jako rodzaj podręcznika lub skryptu książka Literatura i muzyka. Wprowadzenie do problematyki stanowi kompendium wiedzy głównie na temat historii muzyki. Powstała ona z myślą o studentach kierunków filologicznych, których interesuja zagadnienia studiów muzyczno-literackich. Osoby mało zorientowane w historii muzyki otrzymają najpotrzebniejsze informacje dotyczące europejskiej literatury muzycznej, a dodatkowo, dzięki zamieszczonemu na końcu publikacji słowniczkowi najważniejszych pojęć i terminów, przejdą szybki kurs wiedzy o muzyce. Opanowanie tego podstawowego materiału może stać się podstawą do pogłębionych, bardziej szczegółowych studiów. Dlatego lekturę książki należy uznać za pożyteczną i godną polecenia osobom rozpoczynajacym swoją naukową przygodę z niezmiernie szerokim i pasjonującym zagadnieniem związków literatury z muzyką oraz muzyki z literatura.

9 Tamże, s. 104. 


\section{BIBLIOGRAFIA}

Bristiger M., Zwiazki muzyki ze słowem. Z zagadnień analizy muzycznej, Warszawa 1986. Harnoncourt N., Muzyka mowa dźwięków, przeł. M. Czajka, Warszawa 1995.

Harrán D., Word-Tone Relations in Musical Thought. From Antiquity to the Seventeenth Century, Neuhausen-Stuttgart 1986.

Jasiński T., Polska barokowa retoryka muzyczna, Lublin 2006.

Kozłowski K., O libretcie, przemianach $w$ jego rozumieniu $i$ jedności dramatu muzycznego, „Poznańskie Studia Polonistyczne”, Seria Literacka V (XXV), Poznań 1998.

Link K.D., Literarische Perspektiven des Opernlibrettos: Studien zur italienischen Oper von 1850 bis 1920, Bonn 1975.

Pociej B., Mahler, Kraków 1992.

Scher S.P., Literature and music, [w:] Word and Music Studies. Essays on Literature and Music (1967-2004) by Steven Paul Scher, ed. W. Bernhart, W. Wolf, Amsterdam-New York 2004.

Smith P.J., The Tenth Muse: A Historical Study of the Opera Libretto, New York 1970.

Tomaszewski M., Od wyznania do wołania. Studia nad pieśniq romantyczna, Kraków 1997.

Tomaszewski M., W stronę teorii pieśni: zwiazki słowno-muzyczne, [w:] tegoż, Nad pieśniami Karola Szymanowskiego. Cztery studia, Kraków 1998.

Walczak J., Libretto jako (u)twór. Zagadnienia genologiczne i metodologiczne - zarys problematyki, „Przestrzenie Teorii” 2014, nr 22.

Wieczorek R.J., Ut cantus consonet verbis. Zwiazki muzyki ze słowem we włoskiej refleksji muzycznej XVI wieku, Poznań 1995. 